\title{
PENINGKATAN PENGETAHUAN PERAWAT DAN PENDAMPING LANSIA TENTANG MASALAH PSIKOSOSIAL PADA LANSIA DI SATUAN PELAYANAN REHABILITASI SOSIAL LANJUT USIA (RSLU) GARUT
}

\author{
Tanti Suryawantie ${ }^{1}$, Tantri Puspita ${ }^{2}$, Hasbi Taobah Ramdani ${ }^{3}$ Iin Patimah ${ }^{3}$, Evi Siti Nur \\ Faujiah ${ }^{4}$,Yuda Guntama ${ }^{4}$, Faza Fauzan Abdul Azis ${ }^{4}$, Rindi Garuda Perkasa ${ }^{4}$, Astrie \\ Dewi Yuniar ${ }^{4}$, Lisna Latifah ${ }^{4}$, Suci Larasati ${ }^{4}$,Wulandari Febrianti ${ }^{4}$, Muhamad Subki ${ }^{4}$, \\ Silmi Latansa ${ }^{4}$, Rahman Nugraha ${ }^{4}$, Asep Kurnia ${ }^{4}$,Vivi Ahmelia ${ }^{4}$,Novia Nurhadianti ${ }^{4}$ \\ ${ }_{1,3}$ Prodi S1 Keperawatan, STIKes Karsa Husada Garut \\ ${ }^{2}$ Prodi Profesi Ners, STIKes Karsa Husada Garut \\ ${ }^{4}$ Mahasiswa Prodi Profesi Ners, STIKes Karsa Husada Garut
}

Jl. Nusa Indah No.24, Jayaraga, Tarogong Kidul, Kabupaten Garut, Jawa Barat 44151

e-mail: tugasdosentanti2020@gmail.com

\begin{abstract}
ABSTRAK
Secara umum, lansia mengalami kondisi kesakitan karena penurunan fungsi tubuhnya. Adanya kelainan psikososial pada lansia, akan semakin memperparah kesakitan yang dialami oleh lansia tersebut. Perubahan kondisi aspek psikososial terjadi di lingkungan panti. Lansia yang tinggal di panti umumnya menunjukan gejala kecemasan, stress dan depresi. Perawat dan pendamping lansia perlu mengetahui kondisi perubahan psikososial pada lansia. Hal ini berguna sebagai bentuk promosi kesehatan pada lansia. Kegiatan pengabdian masyarakat ini dilaksanakan pada tanggal 16 Januari 2020 di aula Satuan Pelayanan RSLU Kabupaten Garut diikuti oleh 11 orang peserta terdiri perawat dan pendamping lansia. Metode yang digunakan dalam pengabdian mayarakat ini adalah penyuluhan kesehatan tentang masalah-masalah psikososialpada lansia. Sebelum dilakukan penyuluhan tentang masalah-masalah psikososial lansia dilakukan pre-test dan post-test dengan cara menyebarkan kuisioner kepada peserta untuk mengetahui tingkat pengetahuan para peserta tentang materi yang akan dan setelah disampaikan. Dari kegiatan pengabdian masyaraka ini berhasil meningkatkan pengetahuan perawat dan pendamping lansia tentang masalah psikososial yaitu pengetahuan baik menjadi $36 \%$ dari $18 \%$, dan pengetahuan cukup menjadi $64 \%$ dari $45 \%$. Setelah diadakan pengabdian masyarakat ini perlu menindaklanjuti untuk tetap mendampingi perawat dan pendamping lansia dengan meningkatkan keterampilan dalam menghadapi lansia sehingga lansia bisa menerima perubahan fisik dan psikologisnya. Kegiatan yang diberikan bisa berupa pelatihan atau workshop tentang keterampilan komunikasi pada lansia serta keterampilan terapeutik dalam penanganan masalah-masalah psikososial pada lansia.
\end{abstract}

\section{Kata Kunci : Lansia, masalah psikososial, perawat, pendamping lansia}

\section{ABSTRACT}

Generally, the elderly change the conditions of conformity due to a decrease in control functions. The existence of psychosocial disorders in the elderly have aggravate the pain experienced of them. This changes in Conditions Psychosocial aspects had occured in the environment of the orphanage. Many of the elderly who live at homes showing symptoms of stress and depression. So that, the Nurses and the caregivers of the elderly need to know the psychosocial condition in the elderly. This is useful as a form of health promotion in the elderly. This community service activity was carried out on January 16, 2020 in the hall of the Garut District RSLU Services Unit, followed by 11 participants consisting of elderly nurses and the caregivers. The method used in this community service was a health education about psychosocial problems in the elderly. Before counseling about the psychosocial problems of the elderly, pre-test and post-test were carried out by means of questionnaires for participants to find out the level of knowledge of the participants about the material to be and after it was delivered. From the community service activities, it succeeded in increasing the knowledge of the elderly nurses and the caregivers on the psychosocial issue. It was showed that their level of good knowledge had increased to be $36 \%$ from $18 \%$ and adequate knowledge to be $64 \%$ from $18 \%$. After the community service was held, it was necessary to follow up to continue the assisting of the elderly nurses and the caregivers by increasing their skills in improving the elderly so that the elderly can accept their physical and psychological changes. The activities provided can include training or workshops on communication skills in the elderly as well as therapeutic skills in handling psychosocial problems in the elderly.

Key Words: Elderly, pscychosocial problem, nurse, caregivers 


\section{PENDAHULUAN}

Proporsi lansia Indonesia tahun 2035 diprediksi akan mengalami peningkatan sebesar $15,8 \%$ sejak 2017. Hal ini menunjukan bahwa usia lansia dimana seseorang berusia 60 tahun ke atas lebih telah melewati kriteria lebih dari $7,0 \%$. Kriteria ini, memasukan Indonesia berada pada negara yang memasuki aging population Peningkatan ini memaksa pemerintah Indonesia melakukan persiapan memasuki aging population (Lembaga demografi, 2019; BKKBN, 2019). Persiapan ini meliputi kemungkinan munculnya penyakit penyakit yang umumnya diderita oleh lansia seperti penyakit menular ataupun tidak menular, degeneratif ataupun sebaliknya.

Salah satu masalah kesehatan selain penyakit fisik, masalah psikososial juga menjadi hal yang penting untuk diantisipasi. Menurut world health organization (WHO) (2020), secara umum, lansia mengalami kondisi kesakitan karena penurunan fungsi tubuhnya. Adanya kelainan psikososial pada lansia, akan semakin memperparah kesakitan yang dialami oleh lansia tersebut. Lansia mengalami berbagai permasalahan psikologis yang perlu diperhatikan oleh perawat, keluarga maupun petugas kesehatan lainnya (Mendoko, Katuuk dan Rompas, 2017). Menurut Kartinah (2014) dalam Mendoko, Katuuk dan Rompas, (2017) menyebutkan bahwa penanganan masalah secara dini akan membantu lansia dalam melakukan strategi pemecahan masalah tersebut dan dalam beradaptasi untuk kegiatan sehari-hari.

Perubahan psikologis lansia sering terjadi karena perubahan fisik dan mengakibatkan berbagai masalah kesehatan jiwa di usia lanjut di antaranya adalah paranoid, gangguan tingkah laku, gangguan tidur, keluyuran (wandering), lansia mengalami kecemasan meningkat saat menjelang malam (sundowning), depresi, demensia, dan sindrom pasca kekuasaan (post power syndrom) (Yusup, Ah, Rizki Fitryasari, Hanik Endang Nihayati, 2015). Kondisi perubahan aspek psikososial ini perlu ditangani. Perubahan ini, umumnya ditunjukan oleh para lansia dengan menunjukan gejala kecemasan, stress dan depresi (Mendoko, Katuuk dan Rompas, 2017; Safitri, Zulfitri dan Utami, 2020; Khairani dan Ervina, 2012). Banyak penyebab yang menungkinkan hal ini terjadi. Menurut Mendoko, Katuuk dan Rompas (2017), perbedaan jenis suku bangsa pada lansia yang tinggal di Panti Werdha Damai Ranomuut Minahasa menyebabkan para lansia sulit berinteraksi satu sama lain. Sehingga menyebabkan mereka melakukan isolasi sosial.

Dengan demikian, perawat atau pendamping lansia perlu mengetahui kondisi perubahan psikososial pada lansia. Hal ini berguna sebagai bentuk promosi kesehatan pada lansia. Sehingga tercipta kondisi dan lingkungan hidup yang mendukung kesejahteraan lansia tersebut. Diharapkan, lansia dapat menjalani kehidupan yang sehat dengan terpenuhinya kebutuhan mereka secara menyeluruh (WHO, 2020).

Satuan Pelayanan Rehabilitasi Sosial Lanjut usia (RSLU) Garut merupakan salah satu lembaga sosial di bawah dinas sosial Provinsi Jawa Barat yang memberikan pelayanan kepada para lansia yang dirujuk dari masyarakat atau pindahakn dari tempat lain sesuai dengan peraturan yang berlaku. Pada proses pemberian asuhan dan perawatan lansia di Satpel RSLU ini, ditemukan banyak kasus psikososial lansia yang perlu dikenali dan dihadapi oleh para petugas. Sehingga, adanya tukar informasi terkait hal tersebut sangat diperlukan.

\section{METODE}

Kegiatan pengabdian masyarakat ini dilaksanakan pada tanggal 16 Januari 2020 di aula Satpel RSLU Garut. Kegiatan pengabdian masyarakat ini diikuti oleh 11 orang peserta terdiri 3 
orang perawat dan 8 pendamping lansia. Metode yang digunakan dalam pengabdian mayarakat ini adalah penyuluhan kesehatan tentang masalahmasalah psikososial pada lansia dengan metode ceramah dan pemberian leaflet atau brosur kepada peserta. Sebelum dilakukan penyuluhan tentang masalahmasalah psikososial lansia dilakukan pretest dan post-test dengan cara menyebarkan kuisioner kepada peserta untuk mengetahui tingkat pengetahuan para peserta tentang materi yang akan dan setelah disampaikan. Hasil kuisioner tersebut diolah dengan menggunakan analisisi deskriptif dan dituangkan dalam bentuk tabel.

\section{HASIL DAN PEMBAHASAN}

Kegiatan pengabdian masyarakat yang telah dilakukan terdiri dari beberapa rangkain kegiatan dimulai dari kegiatan persiapan, pelaksanaan dan evaluasi kegiatan. Pada tahap persiapan, tim pengabdian masyarakat menyiapkan beberapa peralatan dan instrument yang diperlukan dalam kegiatan ini yaitu satuan acara pembelajaran (SAP), media pembelajaran, leaflet untuk peserta, izin kegiatan, intrument berupa kuisioner untuk mengukur pengetahuan peserta tentang masalah psikososial lansia yang terdiri dari 15 pertanyaan meliputi pengertian,macam-macam masalah psikososial pada lansia, tanda-tanda masalah psikososial pada lansia, tindakan untuk penanganan masalah psikososial pada lansia.

Kegiatan pelaksaan pengabdian masyarakat ini dimulai dengan sambutan dari pihak Satuan pelayanan RSLU Garut, sambutan dari pihak tim pengadian masyarakat. Setelah itu dilakukan pembagian kuisioner untuk melakukan pretest selama 15 menit dan kuisioner dikumpulkan kembali pada tim pengabdian masyarakat. Kemudian dilanjutkan dengan pemaparan materi dan tanya jawab selama 90 menit. Pelaksanaan kegiatan pengabdian masyarakat ini berlangsung lancar dan antusias dari peserta bagus terlihat dari keaktifan peserta pada saat materi berlangung. Evaluasi untuk keberhasilan kegiatan ini adalah setelah sesi tanya jawab selesai kemudian dilakukan sesi post test selama 15 menit untuk mengetahui pengetahuan peserta setelah diberikan penyuluhan. Dengan demikian,pelaksaan penyuluhan ini selama 120 menit.

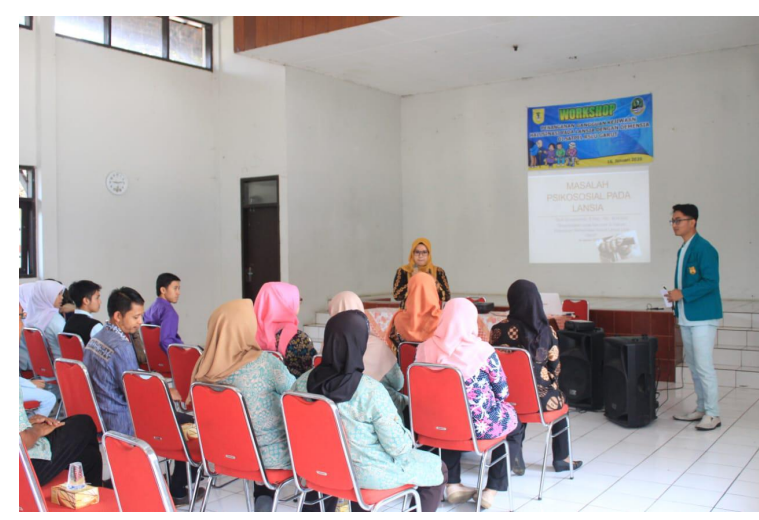

Gambar 1. Kegiatan penyuluhan

Tabel 1. Distribusi frekuensi pengetahuan perawat dan pendamping lansia tentang masalah psikososial pada lansia sebelum penyuluhan kesehatan

\begin{tabular}{llll}
\hline No & Pengetahuan & F & $\%$ \\
\hline 1 & Baik & 2 & $18 \%$ \\
2 & Cukup & 5 & $45 \%$ \\
3 & Kurang & 4 & $37 \%$ \\
& Total & 11 & $100 \%$ \\
\hline
\end{tabular}

Tabel 2. Distribusi frekuensi pengetahuan perawat dan pendamping lansia tentang masalah psikososial pada lansia setelah penyuluhan kesehatan

\begin{tabular}{llll}
\hline No & Pengetahuan & F & $\%$ \\
\hline 1 & Baik & 4 & $36 \%$ \\
2 & Cukup & 7 & $64 \%$ \\
3 & Kurang & 0 & $0 \%$ \\
& Total & 11 & $100 \%$ \\
\hline
\end{tabular}


Hasil analisa pre-test dan post-test yang dilakukan sebelum dan setelah diberikan penyuluhan terlihat bahwa tingkat pengetahuan perawat dan pendamping lansia sebelum penyuluhan kesehatan dan sesudah diberikan penyuluhan mengalami peningkatan pengetahuan. Tingkat pengetahuan perawat dan pendamping lansia sebelum dilakukan penyuluhan menunjukan pengetahuan baik 18\%, pengetahuan cukup $45 \%$ dan pengetahuan kurang $37 \%$. Sedangkan sesudah diberikan penyuluhan tingkat pengetahuan perawat dan pendamping menunjukan pengetahuan baik $36 \%$ ( ada peningkatan 18\%), pengetahuan cukup $64 \%$ ( ada peningkatan 19\%) serta tidak ada lagi yang pengetahuan kurang (0\%). Penyampaian informasi pada pengabdian masyarakat ini dilakukan dengan ceramah dan tanya jawab sesudah penyampaian materi sehingga peserta dapat bertanya tentang hal-hal yang belum dipahaminya. Dengan demikian terjadi interaksi langsung antara pemateri atau narasumber dengan peserta sehingga penyuluhan lebih menarik dan tidak membosankan karena ada proses diskusi antara pemateri dengan peserta.

Peserta setelah diberikan penyuluhan menyampaikan bahwa mengetahui dan lebih memahami terkait dengan pengertian,macam-macam masalah psikososial pada lansia, tandatanda masalah psikososial pada lansia, tindakan untuk penanganan masalah psikososial pada lansia. Selama ini peserta hanya mengetahui masalah psikososial pada lansia adalah demensia, depresi, post power syndrom padahal bukan hanya itu saja. Menurut Yusup, AH, Rizki Fitryasari, Hanik Endang, Nihayati, (2015) masalah psikososial pada lansia adalah paranoid, gangguan tingkah laku, gangguan tidur, keluyuran (wandering), sundowning (lansia mengalami kecemasan meningkat saat menjelang malam), depresi, demensia, sindrom pasca kekuasaan (post power syndrom). Berdasarkan dari pemaparan peserta, lansia di RSLU mengalami masalah psikososial yang dipaparkan oleh pemateri tetapi tidak tahu nama ilmiahnya, contohnya sundowning, wandering,post power syndrom. Selain itu, peserta juga pada saat berinteraksi dengan lansia terkadang kesulitan berkomunikasi dengan lansia jika ada lansia yang sedang mengalami masalah psikososial. Ketika sudah diberikan penyuluhan peserta sudah lebih memahami terkait dengan penanganan masalah akibat perubahan psikologis pada lansia dengan modifikasi lingkungan dan sosial lansia di RSLU. Pihak RSLU sudah mengantisipasi mencegah terjadinya salah satu masalah psikososial yaitu wandering (keluyuran) dengan cara memakaikan gelang identitas pada lansia yang tinggal di RSLU. Hal ini sesuai dengan Yusup, AH, Rizki Fitryasari, Hanik Endang, Nihayati, (2015) menyebutkan bahwa keluyuran (Wandering) pada lansia terjadi akibat bingung dan demensia. Tindakan yang dapat dilakukan adalah diberi tanda pengenal, pagar dikunci apabila ditinggal oleh pendamping.

Kegiatan pengabdian masyarakat ini dengan menggunakan metode ceramah dan media pembelajaran berupa poster, leaflet atau brosur yang diberikan kepada peserta. Peserta setelah diberikan penyuluhan terdapat peningkatan pengetahuan, hal ini sesuai dengan pendapatnya Wahdini (2013) bahwa penyuluhan dengan metode ceramah disertai poster dan penyuluhan dengan metode ceramah disertai media leaflet dapat meningkatkan pengetahuan dan sikap responden. Ceramah adalah metode pendidikan kesehatan dengan menyampaikan secara langsung pesanpesan kesehatan kepada sasaran baik untuk yang berpendidikan tinggi maupun rendah. Kunci dari keberhasilan metode adalah apabila penceramah dapat menguasai isi ceramah dan sasaran ceramah. Metode ini biasanya diterapkan 
pada pendidikan kesehatan perorangan atau kelompok (Notoatmodjo, 2007 dalam Pramiputra, Alfan;Irdawati,Dwi Handoyo ( 2014).

Metode ceramah adalah suatu cara yang digunakan untuk menyampaikan suatu keterangan atau informasi tentang suatu pokok persoalan serta masalah secara lisan (Hamdani, 2011). Metode ceramah merupakan salah satu metode yang paling sering digunakan dalam pendidikaan kesehatan, hal ini di anggap sebagai metode yang paling mudah dilaksanakan, dengan menguasai materi yang akan disampaikan penyuluh tinggal menyajikanya dihadapan responden. Hal tersebut sesuai dengan penelitian yang dilakukan oleh Qoriah (2010) dalam Pramiputra, Alfan, Irdawati, Dwi Handoyo (2014) bahwa dengan ceramah dapat meningkatkan pengetahuan seseorang. Hal ini sesuai dengan hasil post-test pada kegiatan pengabdian masyarakat ini yaitu ada peningkatan nilai tingkat pengetahuan menunjukan pengetahuan baik dengan peningkatan $18 \%$ ( pretest $18 \%$ dan post test $36 \%$ ), pengetahuan cukup terdapat peningkatan $19 \%$ ) serta tidak ada lagi yang pengetahuan kurang $(0 \%)$. Pengetahuan adalah merupakan hasil tahu yang terjadi setelahb ornag mengadakan penginderaan terhadap suatu objek tertentu. Penginderaan terhadap objek terjadi melalui panca indera seperti penglihatan, penciuman, pendengaran,perasa dan peraba dengan sendiri. Pengetahuan merupakan salah satu faktor yang mempengaruhi terbentuknya sikap seseorang ( Notoadtmojo,2010)

Beberapa kelebihan metode ceramah menurut Syaiful bahri (2010) dalam Pramiputra, Alfan, Irdawati, Dwi Handoyo (2014) penyuluh mudah menguasai responden, dapat diikuti orang banyak, relatif mudah dalam menyiapkan dan melaksanakanya, teknik ceramah yang baik dapat mendukung tercapainya penyerapan dan pemahaman materiyang baik. Setelah seseorang mengetahui objek atau stimulus, proses selanjutnya adalah memiliki atau bersikap terhadap stimulus atau objek tersebut. Hal ini sesuai dengan penelitaian Putri, Rindy Ayu (2017) tentang Efektivitas Metode Ceramah dengan Media Powerpoint dan Leaflet dalam Peningkatan pengetahuan dan Sikap Wanita Usia Subur (WUS) tentang Kanker Serviks di Wilayah Kerja Puskesmas Helvetia Kecamatan Medan Helvetia Tahun 2016 bahwa metode ceramah merupakan stimulus atau objek yang diharapkan dapat member pengaruh pada responden untuk bersikap sesuai dengan materi dari ceramah yang disampaikan.

Selain menggunakan metode ceramah,penyuluhan ini juga menggunakan media leaflet sebagai sarana belajarnya. Leaflet adalah bentuk penyampaian informasi atau pesan-pesan kesehatan melalui lembaran yang dilipat, isi informasi dapat dalam bentuk kalimat maupun gambar, atau kombinasi keduanya, Media leaflet mempunyai kelebihan dapat menyesuaikan masyarakat belajar mandiri, masyarakat dapat melihat isinya lebih santai, informasi dapat dibagi baik dengan keluarga dan tetangga, dapat memberikan detail menggunakan gambar untuk penguatan pesan (Notoatmodjo, 2005 dalam Putri, Rindy Ayu (2017) .

Selain itu leaflet bersifat praktis karena dapat dibawa kemana-mana dan informasi yang tersaji pun jelas sehingga mudah dibaca dimanapun dan kapanpun (Gani, 2014). Beberapa kelebihan leaflet menurut I Putu dan I Dewa (2012) dalam Pangesti, Henning Dwi. Dwi Prihatiningsih (2010) adalah dapat disimpan lama, sasaran dapat menyesuaikan dan belajar mandiri, dapat dibaca berulang-ulang, jangkauan sasaran lebih luas, isi dapat dicetak kembali. Hal ini sesuai dengan yang disampaikan oleh Azwar (2007) dalam Pangesti, Henning Dwi. Dwi Prihatiningsih (2010) bahwa penggunaan berbagai bentuk media 
mempunyai pengaruh besar dalam pembentukan opini dan kepercayaan seseorang. Selain itu didukung oleh penelitian Subarniati, dkk (1996) bahwa media yang bersifat visual paling efektif (83\%) dibandingkan dengan media lain sebagai stimulasi informasi sugesti (Pangesti, Henning Dwi. Dwi Prihatiningsih , 2010)

Pemberian informasi dalam bentuk ceramah dan media belajar leaflet ternyata mampu meningkatkan pengetahuan perawat dan pendamping lansia di satuan pelayanan RSLU meskipun hasilnya beragam karena dipengaruhi juga oleh faktor latar pendidikan yang berbeda-beda mulai dari SD, SMP,SMA dan Perguruan tinggi serta lama bekerja di satuan pelayanan RSLU. Lama bekerja ada yang baru empat tahun bahkan ada yang sudah mengabdi hampir 26 tahun. Hal ini sesuai dengan pendapatnya Rahayu (2010) bahwa dalam memberikan penyuluhan terdapat faktor-faktor yang mempengaruhi keberhasilan suatu penyuluhan diantaranya adalah pendidikan, sosial ekonomi, adat istiadat, kepercayaan masyarakat dan ketersediaan waktu.

\section{KESIMPULAN DAN SARAN}

Kegiatan pengabdian masyarakat berupa peyuluhan kesehatan peningkatan pengetahuan perawat dan pendamping lansia tentang masalah psikososial lansia telah dilaksanakan di Satuan pelayanan RSLU Kabupaten Garut pada tanggal 16 Januari 2020. Peningkatan pengetahuan masalah psikososial pada lansia dengan cara memberikan penyuluhan kesehatan mengenai masalah psikososial lansia dengan metode ceramah dan pembagian leaflet. Dari kegiatan penyuluhan berhasil meningkatkan pengetahuan perawat dan pendamping lansia tentang masalah psikososial setelah diberikan penyuluhan dengan nilai post-test pengetahuan baik $36 \%$, pengetahuan cukup $64 \%$ dan tidak ada yang memiliki pengetahuan kurang.
Setelah diadakan pengabdian masyarakat ini perlu menindaklanjuti untuk tetap mendampingi perawat dan pendamping lansia dengan meningkatkan keterampilan komunikasi dalam menghadapi lansia yang memiliki masalah-masalah psikososial sehingga lansia bisa menerima perubahan fisik dan psikologisnya. Penanganan terhadap berbagai masalah yang terjadi pada lansia harus dilakukan secara utuh dan menyeluruh dengan memperhatikan kebutuhan biologis, psikologis serta sosial lansia sepanjang hidupnya. Kegiatan yang diberikan bisa berupa pelatihan atau workshop tentang keterampilan komunikasi pada lansia serta keterampilan terapeutik dalam penanganan masalah-masalah psikososial pada lansia.

\section{UCAPAN TERIMA KASIH}

Puji syukur kami panjatkan ke hadirat Allah SWT berkat rahmat dan inayah-NYA kami bisa memberikan pengabdian kepada masyarakat berupa peyuluhan kesehatan kepada perawat dan pendamping lansia di Satuan Pelayanan Reahabilitasi Mental Lanjut Usia (RSLU) Garut. Ucapan terima kasih juga kami sampaikan kepada Kepala RSLU Kabupaten Garut beserta staf, perawat dan pendamping lansia yang telah memberikan izin dan kesempatan kepada kami untuk melakukan pengabdian masyarakat, Ketua STIKes Karsa Husada Garut beserta jajaran, Ketua Prodi S1 Keperawatan, Ketua Prodi Profesi Ners, serta mahasiswa profesi ners dan pihak lainnya yang telah membantu pelaksanaan kegiatan pengabdian masyarakat ini sehingga berjalan lancar dan sesuai dengan terget yang diharapkan. 


\section{DAFTAR PUSTAKA}

Gani, H. A., Istiaji, E., Kusuma, A. I., 2014. Perbedaan Efektivitas Leaflet dan Poster Produk Komisi Penanggulangan HIV AIDS Kabupaten Jember Dalam Perilaku Pencegahan HIV AIDS. Jurnal IKESMA 10

Hamdani. (2011). Strategi Belajar Mengajar. Bandung: Pustaka Setia

Khairani dan Ervina. 2020. Hubungan Perubahan Psikososial dengan Kualitas Hidup Lansia. Diperoleh tanggal 3 April 2020. dari: jurnal. Unsyiah.ac.id.

WHO. 2020. Mental Health of Older Adults. Diperoleh tanggal 4 Maret 2020.

Dari:

https://www.who.int/news-

room/fact-sheets/detail/mentalhealth-of-older-adults

Mendoko, F., Katuuk, M., dan Rompas, S.(2017). Perbedaan Status Psikososial Lanjut Usia Yang Tinggal Di Panti Werdha Damai Ranomuut Manado dengan yang Tinggal Bersama Keluarga Di Desa Sarongsong II Kecamatan Airmadidi Kabupaten Minahasa Utara. Diakses dari:Diperoleh tanggal 2 April 2020. Dari

https://media.neliti.com/media/public ations/106076-ID-perbedaan-statuspsikososial-lanjut-usia.pdf

Notoatmodjo , S.2010. Promosi Kesehatan dan ilmu perilaku. Jakarta: Rineka Cipta

Pangesti, Henning Dwi. Dwi Prihatiningsih. 2010. Studi komparasi metode ceramah dan leaflet terhadap tingkat pengetahuan dan sikap remaja tentang vulva hygiene di SMAN 10 Puerworejo. http://digilib.unisayogya.ac.id/1743/ 1/NASPUB.pdf

Pramiputra, Alfan;Irdawati,Dwi Handoyo. 2014. Efektifitas pendidikan kesehatan menggunakan metode ceramah dengan leaflet terhdapa peningkatan pengetahuan pencegahan demam berdarah dengue di desa Wonorejo. http://eprints.ums.ac.id/32335/13/2. $\% 20$ NASKAH $\% 20$ PUBLIKASI.pdf Putri, Rindy Ayu.2017 Efektivitas Metode Ceramah denganMedia Powerpoint dan Leaflet dalamPeningkatanpengetahuan dan SikapWanita Usia Subur (WUS) tentangKanker Serviks di Wilayah KerjaPuskesmas Helvetia KecamatanMedan Helvetia Tahun 2016. http://repositori.usu.ac.id

Safitri, M., Zulfitri, R., Utami, S., (2020). Hubungan Kondisi Kesehatan Psikososial lansia dengan tingkat kemandirian lansia dalam Aktivitas Sehari-hari di Rumah. Diperoleh tanggal 3 April 2020. dari:jim.unri.ac.id

Wahdini. 2013. Pengaruh penyuluhan oleh tenaga pelaksana gizi dengan metode ceramah disertai poster dan leaflet terhadap perilaku ibu dan pertumbuhan balita gizi kurang di kecamatan tanjung beringin

Yusup, Ah. Rizki Fitryasari, Hanik Endang Nihayati. 2015. Buku Ajar Keperawatan Kesehatan Jiwa. Jakarta: Salemba medika 